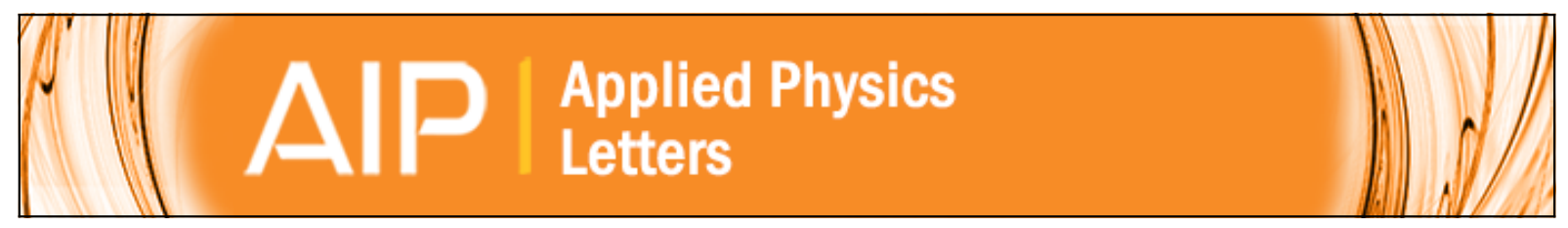

\title{
Nanoparticle iron-phosphate anode material for Li-ion battery
}

Dongyeon Son, Eunjin Kim, Tae-Gon Kim, Min Gyu Kim, Jaephil Cho, and Byungwoo Park

Citation: Applied Physics Letters 85, 5875 (2004); doi: 10.1063/1.1835995

View online: http://dx.doi.org/10.1063/1.1835995

View Table of Contents: http://scitation.aip.org/content/aip/journal/apl/85/24?ver=pdfcov

Published by the AIP Publishing

\section{Articles you may be interested in}

Self-limiting lithiation of electrode nanoparticles in Li-ion batteries

J. Appl. Phys. 114, 223514 (2013); 10.1063/1.4844535

Tin-phosphate glass anode for sodium ion batteries

APL Mat. 1, 052101 (2013); 10.1063/1.4826938

Pure and Li-doped $\mathrm{NiTiH}$ : Potential anode materials for Li-ion rechargeable batteries

Appl. Phys. Lett. 103, 033902 (2013); 10.1063/1.4813596

LiFePO4 - 3D carbon nanofiber composites as cathode materials for Li-ions batteries

J. Appl. Phys. 111, 064307 (2012); 10.1063/1.3693575

Fe-rich and Mn-rich nanodomains in Li 1.2 Mn 0.4 Fe $0.4 \mathrm{O} 2$ positive electrode materials for lithium-ion batteries Appl. Phys. Lett. 91, 054103 (2007); 10.1063/1.2757587

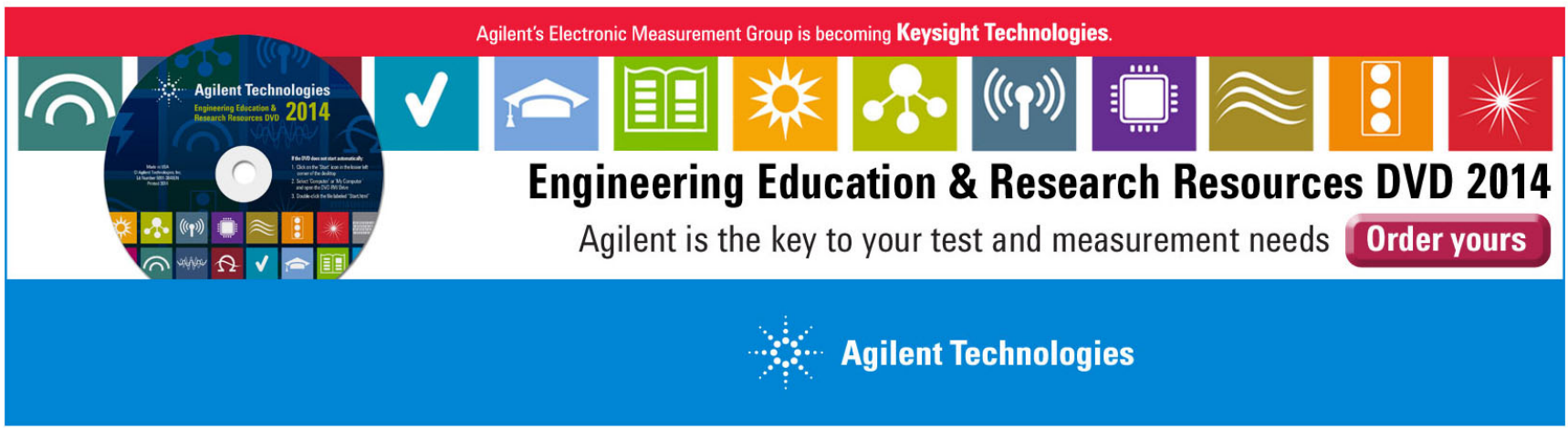




\title{
Nanoparticle iron-phosphate anode material for Li-ion battery
}

\author{
Dongyeon Son \\ School of Materials Science and Engineering, and Research Center for Energy Conversion and Storage, \\ Seoul National University, Seoul, Korea \\ Eunjin Kim \\ Department of Applied Chemistry, Kumoh National Institute of Technology, Gumi, Korea \\ Tae-Gon Kim \\ School of Materials Science and Engineering, and Research Center for Energy Conversion and Storage, \\ Seoul National University, Seoul, Korea \\ Min Gyu Kim \\ Beamline Research Division, Pohang Accelerator Laboratory, Pohang University of Science \\ and Technology, Pohang, Korea \\ Jaephil Cho \\ Department of Applied Chemistry, Kumoh National Institute of Technology, Gumi, Korea \\ Byungwoo Park ${ }^{\mathrm{a})}$ \\ School of Materials Science and Engineering, and Research Center for Energy Conversion and Storage, \\ Seoul National University, Seoul, Korea
}

(Received 17 August 2004; accepted 20 October 2004)

\begin{abstract}
Nanoparticle crystalline iron phosphates $\left(\mathrm{FePO}_{4} \cdot 2 \mathrm{H}_{2} \mathrm{O}\right.$ and $\left.\mathrm{FePO}_{4}\right)$ were synthesized using a (CTAB) surfactant as an anode material for $\mathrm{Li}$ rechargeable batteries. The electrochemical properties of the nanoparticle iron phosphates were characterized with a voltage window of 2.4-0 V. A variscite orthorhombic $\mathrm{FePO}_{4} \cdot 2 \mathrm{H}_{2} \mathrm{O}$ showed a large initial charge capacity of $609 \mathrm{mAh} / \mathrm{g}$. On the other hand, a tridymite triclinic $\mathrm{FePO}_{4}$ exhibited excellent cyclability: the capacity retention up to 30 cycles was $\sim 80 \%$, from 485 to $375 \mathrm{mAh} / \mathrm{g}$. The iron phosphate anodes exhibited the highest reported capacity, while the cathode $\mathrm{LiFePO}_{4}$ has an ideal capacity of $170 \mathrm{mAh} / \mathrm{g}$. () 2004 American Institute of Physics. [DOI: 10.1063/1.1835995]
\end{abstract}

Since the introduction of commercial lithium-ion batteries for portable devices in the 1990s, the development of new anode materials is essential for improving the energy density. ${ }^{1}$ The graphite generally used in lithium rechargeable batteries has a capacity of $372 \mathrm{mAh} / \mathrm{g}$. These capacity limitations have inspired researchers to find alternative anode materials. Li-Sn alloy has been studied due to its high capacity compared to commercial graphite. ${ }^{2-4}$ However, Snmetal anode has a problem with severe capacity fading due to structural instability related to large volume changes.

Iron phosphates have been explored as cathode materials only. ${ }^{5,6}$ Padhi et al. reported an olivine-type $\mathrm{LiFePO}_{4}$ cathode, which has a theoretical capacity of $170 \mathrm{mAh} / \mathrm{g}$. As lithium is intercalated/deintercalated from the octahedral sites, olivine-type $\mathrm{LiFePO}_{4}$ has a flat voltage plateau at $3.4 \mathrm{~V}$ versus Li. In addition, iron phosphates exhibited different types of structures depending on the synthesis conditions. For instance, $\mathrm{FePO}_{4}$ showed a trigonal structure at normal pressure, but converted to orthorhombic structure at high pressure. $^{7}$ More recently, Song et $a l^{8}{ }^{8}$ and Reale et al. ${ }^{9}$ reported monoclinic (with a space group $P 2_{1} / n$ ), orthorhombic (with $\mathrm{Pbca}$ ), or hexagonal (with $\mathrm{P6}_{3} m c$ ) $\mathrm{FePO}_{4}$. These iron phosphates exhibited an open circuit voltage of approximately $4 \mathrm{~V}$, and showed a voltage plateau at $\sim 3 \mathrm{~V}$ (working as cathodes) with discharge capacities below $100 \mathrm{mAh} / \mathrm{g}$.

We report here a possibility of iron phosphates as anode materials for Li rechargeable batteries. Despite iron phos-

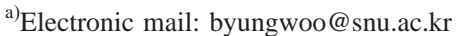

phates being briskly investigated as a positive electrode, the anode materials of $\mathrm{FePO}_{4}$ have not been reported. The capacity of synthesized nanoparticle iron phosphates is approximately three times higher than the ideal capacity of the $\mathrm{LiFePO}_{4}$ cathode.

The $\mathrm{FePO}_{4} \cdot 2 \mathrm{H}_{2} \mathrm{O}$ was fabricated by using a cationic surfactant, cetyl-trimethyl-ammonium bromide (CTAB). The CTAB surfactant $(1.4 \mathrm{~g})$ was added to distilled water $(20 \mathrm{ml})$ and stirred for $30 \mathrm{~min}$. Then, $\mathrm{FeCl}_{3} \cdot 6 \mathrm{H}_{2} \mathrm{O}(3 \mathrm{~g})$ and $\mathrm{H}_{3} \mathrm{PO}_{4}(6.5 \mathrm{~g})$ were gradually added to the solution, and stirred until they were completely dissolved. Subsequently, the suspensions were aged at $90{ }^{\circ} \mathrm{C}$ for a week in an oven. The resultant was then washed with de-ionized water, filtered off, and dried at $100{ }^{\circ} \mathrm{C}$ for $4 \mathrm{~h}$. The tridymite $\mathrm{FePO}_{4}$ was obtained from dehydration of $\mathrm{FePO}_{4} \cdot 2 \mathrm{H}_{2} \mathrm{O}$ at $400{ }^{\circ} \mathrm{C}$ annealing for $8 \mathrm{~h}$ in a furnace.

The electrode composition was iron-phosphate anode : binder : carbon black in a weight ratio of $3: 1: 1$. A slurry was then prepared by mixing them with a $N$-methyl2-pyrrolidone (NMP) solution. The coin-type half cells (2016 size) prepared in an argon-filled glove box contained an ironphosphate anode, a Li metal counter electrode, and a microporous polyethylene separator. The electrolyte used was 1 $\mathrm{M} \mathrm{LiPF}_{6}$ with ethylene carbonate/diethylene carbonate/ethylmethyl carbonate (EC/DEC/EMC). The cycle life of the cells was performed at a rate of $61 \mathrm{~mA} / \mathrm{g}$ for $\mathrm{FePO}_{4} \cdot 2 \mathrm{H}_{2} \mathrm{O}$, and $49 \mathrm{~mA} / \mathrm{g}$ for $\mathrm{FePO}_{4}$ between a voltage window of 2.4 and $0 \mathrm{~V}$. Note that open circuit voltages of our samples were around $2 \mathrm{~V}$. For the XRD measurements, the cells were dis- 


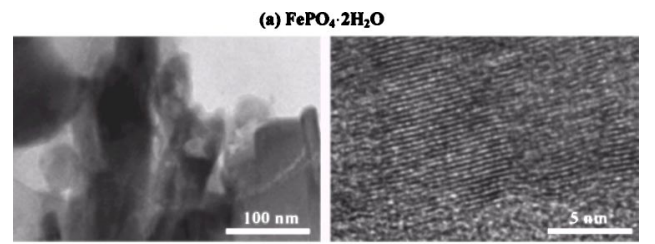

(b) FePO,

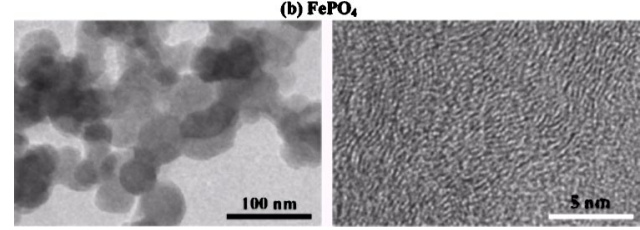

FIG. 1. High-resolution TEM images of the iron phosphates: (a) assynthesized $\mathrm{FePO}_{4} \cdot 2 \mathrm{H}_{2} \mathrm{O}$, and (b) $\mathrm{FePO}_{4}$ (annealed at $400{ }^{\circ} \mathrm{C}$ for $8 \mathrm{~h}$ ).

assembled in a glove box $\left(\mathrm{H}_{2} \mathrm{O}\right.$ level $\left.<50 \mathrm{ppm}\right)$, and the cycled iron-phosphate powders were rinsed thoroughly with a DMC solution to remove any $\mathrm{LiPF}_{6}$ salts.

As shown in Fig. 1, transmission electron microscopy (TEM) was used to identify the microstructures of the iron phosphates. The average nanoparticle size confirmed by TEM is approximately $100 \mathrm{~nm}$ for $\mathrm{FePO}_{4} \cdot 2 \mathrm{H}_{2} \mathrm{O}$, and $\sim 50 \mathrm{~nm}$ for $\mathrm{FePO}_{4}$. These are in good agreement with the $\mathrm{x}$-ray diffraction patterns shown in Fig. 2. The size estimated from the Scherrer formula of $\Delta k$ versus $k$ (the scattering vector) was a few hundred nanometers for $\mathrm{FePO}_{4} \cdot 2 \mathrm{H}_{2} \mathrm{O}$, and $\sim 40 \mathrm{~nm}$ for $\mathrm{FePO}_{4}$. Interestingly, a high-resolution TEM shows that both orthorhombic $\mathrm{FePO}_{4} \cdot 2 \mathrm{H}_{2} \mathrm{O}$ and triclinic $\mathrm{FePO}_{4}$ have a nanostructured periodicity $(\sim 0.3 \mathrm{~nm})$. This curling-shaped nano-periodicity was also observed in carbon, $\mathrm{WS}_{2}, \mathrm{Ga}_{2} \mathrm{O}_{3}, \mathrm{~V}_{2} \mathrm{O}_{5}$, etc. ${ }^{10-15}$ More detailed studies of the role of nanostructures on the electrochemical properties are currently underway. Amorphous iron-phosphate anodes showed a rapid capacity decay, thus showing less than

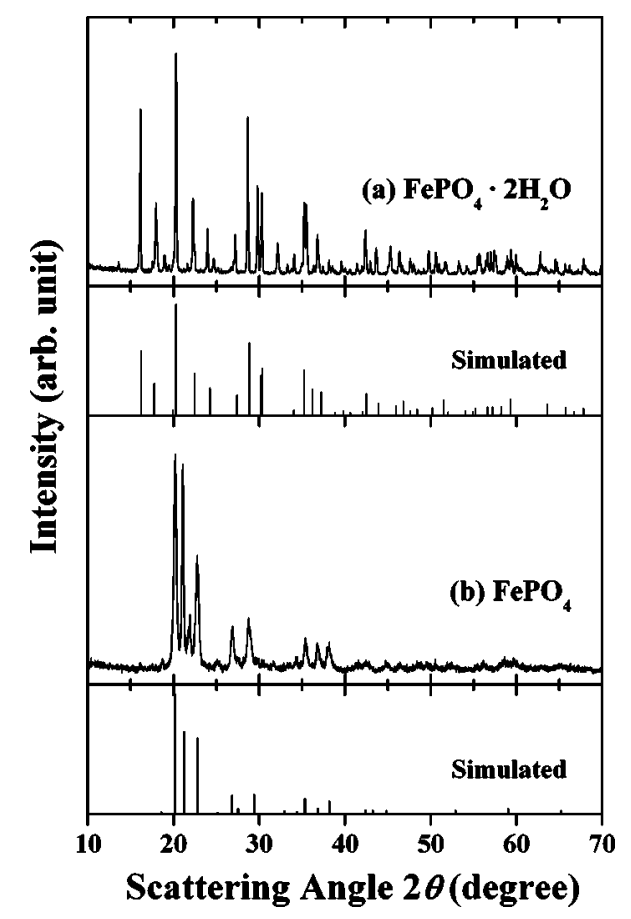

FIG 2 Measured and simulated $x$-ray diffraction patterns of (a) assynthesized $\mathrm{FePO}_{4} \cdot 2 \mathrm{H}_{2} \mathrm{O}$, and (b) $\mathrm{FePO}_{4}$ (annealed at $400{ }^{\circ} \mathrm{C}$ for $8 \mathrm{~h}$ ).

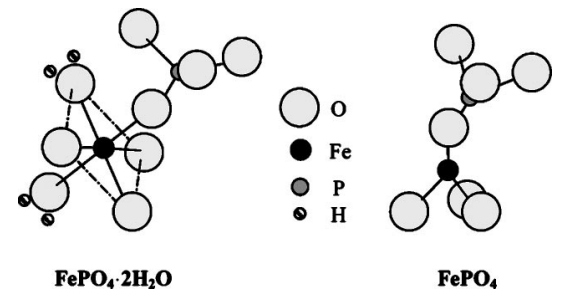

FIG. 3. Schematic representation of the basic crystal structures of iron phosphates: the variscite orthorhombic $(\mathrm{Pbca}) \mathrm{FePO}_{4} \cdot 2 \mathrm{H}_{2} \mathrm{O}$ and tridymite triclinic $(P 1) \mathrm{FePO}_{4}$

$100 \mathrm{mAh} / \mathrm{g}$ after 10 cycles, even with a similar initial-charge capacity. ${ }^{16}$

The crystal structure of the as-synthesized iron phosphate was very similar to the one reported in the literature for the variscite $\mathrm{AlPO}_{4} \cdot 2 \mathrm{H}_{2} \mathrm{O}$ or $\mathrm{GaPO}_{4} \cdot 2 \mathrm{H}_{2} \mathrm{O}$. ${ }^{17,18}$ Using the simulation technique $\left(\mathrm{ATOMS}^{19}\right.$ ) after replacing $\mathrm{Al}$ with $\mathrm{Fe}$, the crystal structure of the as-prepared iron phosphate was identified as an orthorhombic $\mathrm{FePO}_{4} \cdot 2 \mathrm{H}_{2} \mathrm{O}$, which is a variscite structure with the space group Pbca [Fig. 2(a)], with lattice parameters of $a=0.9926 \mathrm{~nm}, b=0.8619 \mathrm{~nm}$, and $c=0.9976 \mathrm{~nm}$. After annealing at $400{ }^{\circ} \mathrm{C}$ for $8 \mathrm{~h}$, the water molecules in $\mathrm{FePO}_{4} \cdot 2 \mathrm{H}_{2} \mathrm{O}$ were successfully removed, and the XRD data of Fig. 2(b) confirmed a triclinic $\mathrm{FePO}_{4}$ phase, which has a space group $P 1$ with $a=1.0163 \mathrm{~nm}, b$ $=1.7624 \mathrm{~nm}, c=8.3733 \mathrm{~nm}$, and $\alpha=90.01^{\circ}, \beta=90.03^{\circ}, \gamma$ $=89.98^{\circ}$. The schematic figures of the variscite $\mathrm{FePO}_{4} \cdot 2 \mathrm{H}_{2} \mathrm{O}$ and tridymite $\mathrm{FePO}_{4}$ are shown in Fig. 3.

To investigate the superior electrochemical properties of iron phosphates, coin-type half cells were cycled in extreme conditions, between 2.4 and $0 \mathrm{~V}^{20-22}$ Analogous tinphosphate anode showed severe capacity fading even between 1.5 and $0 \mathrm{~V}$, and getting much worse with higher cutoff voltages. ${ }^{1}$ Figure 4 shows the voltage profiles and capacity retention of the variscite $\mathrm{FePO}_{4} \cdot 2 \mathrm{H}_{2} \mathrm{O}$ and the
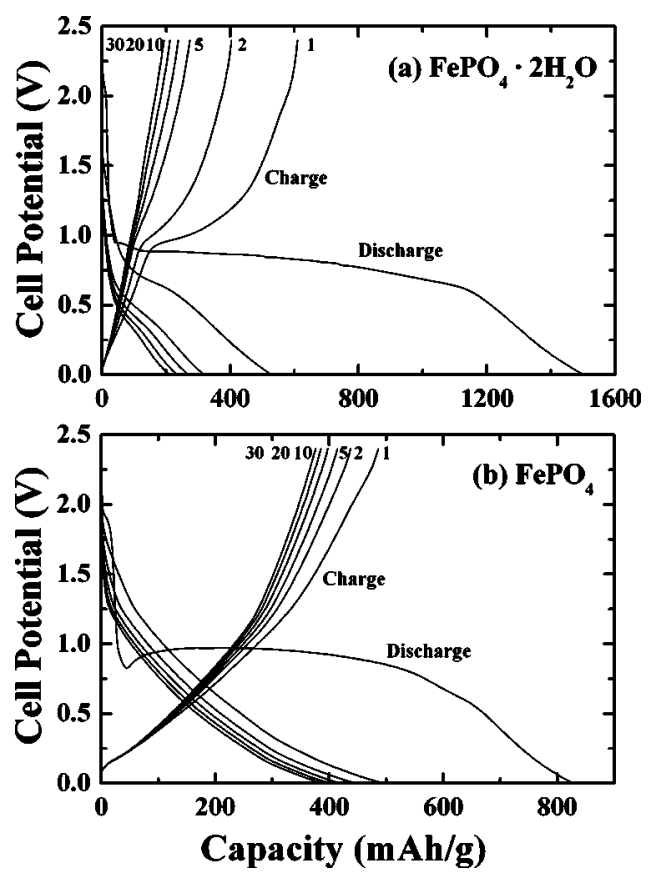

FIG. 4. Voltage profiles of the iron phosphates between 2.4 and $0 \mathrm{~V}$. The cells were cycled at (a) $61 \mathrm{~mA} / \mathrm{g}$ for variscite $\mathrm{FePO}_{4} \cdot 2 \mathrm{H}_{2} \mathrm{O}$ (initial capacity of $609 \mathrm{mAh} / \mathrm{g}$ ) and (b) $49 \mathrm{~mA} / \mathrm{g}$ for tridymite $\mathrm{FePO}_{4}$ (initial canacity of $485 \mathrm{mAh} / \mathrm{g}$ ). 


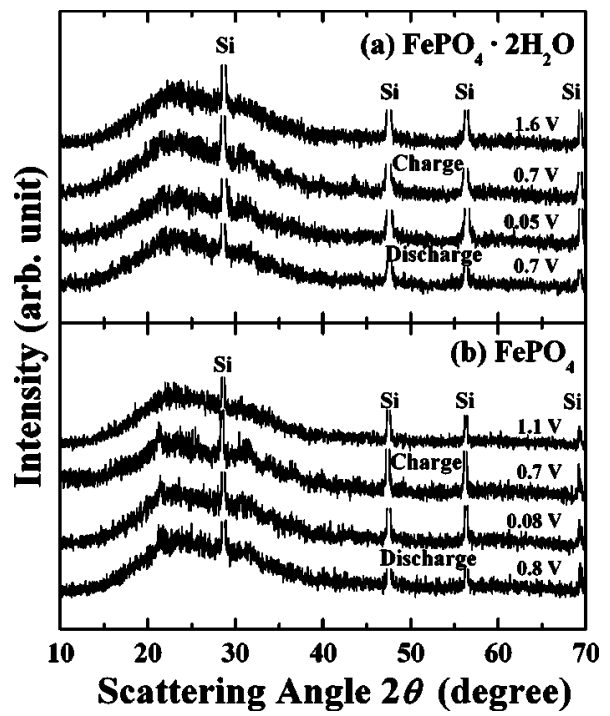

FIG. 5. XRD patterns of (a) the cycled $\mathrm{FePO}_{4} \cdot 2 \mathrm{H}_{2} \mathrm{O}$ and (b) cycled $\mathrm{FePO}_{4}$, during the first discharge and charge at a specific voltage.

tridymite $\mathrm{FePO}_{4}$. The initial charge capacity of the $\mathrm{FePO}_{4} \cdot 2 \mathrm{H}_{2} \mathrm{O}$ is high $(609 \mathrm{mAh} / \mathrm{g})$, but the capacity faded noticeably during cycling. In contrast, the tridymite $\mathrm{FePO}_{4}$ had an initial charge capacity of $485 \mathrm{mAh} / \mathrm{g}$, which is approximately three times higher than the ideal capacity of cathode $\mathrm{LiFePO}_{4}$. In addition, the capacity retention [Fig. 4(b)] at a rate of $49 \mathrm{~mA} / \mathrm{g}$ up to 30 cycles was $\sim 80 \%$ (from 485 to $375 \mathrm{mAh} / \mathrm{g}$ ). It should be noted that the irreversible capacity of the variscite $\mathrm{FePO}_{4} \cdot 2 \mathrm{H}_{2} \mathrm{O}$ anode $(\sim 897 \mathrm{mAh} / \mathrm{g})$ is larger than the tridymite $\mathrm{FePO}_{4}(\sim 344 \mathrm{mAh} / \mathrm{g})$, which is probably due to the side reactions with both the $\mathrm{H}_{2} \mathrm{O}$ molecules and residual surfactants.

The electrochemical reactions of cathode $\mathrm{LiFePO}_{4}$ involved the $\mathrm{Fe}^{3+} / \mathrm{Fe}^{2+}$ redox coupling. Therefore, the theoretical capacity of the $\mathrm{LiFePO}_{4}$ cathode is only $170 \mathrm{mAh} / \mathrm{g}$. However, iron-phosphate anodes can have a high capacity, probably due to the $\mathrm{Fe}^{3+} / \mathrm{Fe}^{2+} / \mathrm{Fe}^{0}$ redox reactions. Poizot et $a l^{23}$ reported that the $3 d$ transition-metal oxides could be reversibly reduced and oxidized, coupled with the formation/ destruction of $\mathrm{Li}_{2} \mathrm{O}$, with the formation of a nanoparticle $3 d$ transition metal. Analogous reactions may apply to iron phosphates, and more detailed experiments (Mössbauer, XANES, etc.) are currently underway to identify the reaction mechanisms. To confirm the phases during discharging/ charging, the XRD patterns of both $\mathrm{FePO}_{4} \cdot 2 \mathrm{H}_{2} \mathrm{O}$ and $\mathrm{FePO}_{4}$ were investigated (Fig. 5). As the anode was discharged (lithiated) to $0 \mathrm{~V}$, the crystalline peaks of the $\mathrm{FePO}_{4} \cdot 2 \mathrm{H}_{2} \mathrm{O}$ and $\mathrm{FePO}_{4}$ disappeared, indicating an amorphous or nanocrystalline state.
In conclusion, nanoparticle iron phosphates $\left(\mathrm{FePO}_{4} \cdot 2 \mathrm{H}_{2} \mathrm{O}\right.$ and $\left.\mathrm{FePO}_{4}\right)$ were achieved using a CTAB surfactant as a new anode material for $\mathrm{Li}$ rechargeable batteries. The synthesized triclinic iron phosphate exhibited excellent cyclability: the capacity retention up to 30 cycles was $\sim 80 \%$, from 485 to $375 \mathrm{mAh} / \mathrm{g}$. Also, the capacity is approximately three times higher than the ideal value of cathode $\mathrm{LiFePO}_{4}$. This original nanoparticle iron phosphate demonstrates a potential for use as Li battery anode materials.

The authors thank Chunjoong Kim for the TEM measurements. This work was supported by the National R\&D Program of the Ministry of Science and Technology, the Basic Research Program (R01-2004-000-10173-0) of KOSEF, the Ministry of Information and Communication (MIC) in Korea, and KOSEF through the Research Center for Energy Conversion and Storage at Seoul National University.

${ }^{1}$ Y. Idota, T. Kubota, A. Matsufuji, Y. Maekawa, and T. Miyasaka, Science 276, 1395 (1997).

${ }^{2}$ D. Aurbach, A. Nimberger, B. Markovsky, E. Levi, E. Sominski, and A. Gedanken, Chem. Mater. 14, 4155 (2002).

${ }^{3}$ I. A. Courtney and J. R. Dahn, J. Electrochem. Soc. 144, 2943 (1997).

${ }_{4}^{4}$ J.-M. Tarascon and M. Armand, Nature (London) 414, 359 (2001).

${ }^{5}$ A. K. Padhi, K. S. Nanjundaswamy, and J. B. Goodenough, J. Electrochem. Soc. 144, 1188 (1997).

${ }^{6}$ S.-Y. Chung, J. T. Blocking, and Y.-M. Chiang, Nat. Mater. 1, 123 (2002). ${ }^{7}$ M. P. Pasternak, G. K. Rozenberg, A. P. Milner, M. Amanowicz, U. Schwaez, K. Syassen, R. D. Taylor, M. Hanfland, and K. Brister, Phys. Rev. Lett. 79, 4409 (1997).

${ }^{8}$ Y. Song, P. Y. Zavalij, M. Suzuki, and M. S. Whittingham, Inorg. Chem. 41, 5778 (2002)

${ }^{9}$ P. Reale, B. Scrosati, C. Delacourt, C. Wurm, M. Morcrette, and C. Masquelier, Chem. Mater. 15, 5051 (2003).

${ }^{10}$ T. Hyeon, S. Han, Y.-E. Sung, K.-W. Park, and Y.-W. Kim, Angew. Chem., Int. Ed. 42, 4352 (2003).

${ }^{11}$ T.-W. Kim, I.-S. Park, and R. Ryoo, Angew. Chem., Int. Ed. 42, 4375 (2003).

${ }^{12}$ Y. D. Li, X. L. Li, R. R. He, J. Zhu, and Z. X. Deng, J. Am. Chem. Soc. 124, 1411 (2002).

${ }^{13}$ U. M. Graham, S. Sharma, M. K. Sunkara, and B. H. Davis, Adv. Funct. Mater. 13, 576 (2003).

${ }^{14}$ M. E. Sphar, P. Bitterli, R. Nesper, M. Muller, F. Krumeich, and H. U. Nissen, Angew. Chem., Int. Ed. 37, 1263 (1998).

${ }^{15}$ G. R. Ratzke, F. Krumeich, and R. Nesper, Angew. Chem., Int. Ed. 41, 2447 (2002).

${ }^{16}$ J. Cho, D. Son, and B. Park (unpublished).

${ }^{17}$ A. M. Beale and G. Sankar, J. Mater. Chem. 12, 3064 (2002).

${ }^{18}$ H. Graetsch, Acta Crystallogr., Sect. C: Cryst. Struct. Commun. 56, 401 (2000).

${ }^{19}$ E. Dowty, Aтомs. Shape software, 521 Hidden Valley Road, Kingsport, Tennessee, 2002.

${ }^{20}$ Y. J. Kim, H. Kim, B. Kim, D. Ahn, J.-G. Lee, T.-J. Kim, D. Son, J. Cho, Y.-W. Kim, and B. Park, Chem. Mater. 15, 1505 (2003).

${ }^{21}$ J. Cho, Y. J. Kim, T.-J. Kim, and B. Park, Angew. Chem., Int. Ed. 40, 3367 (2001).

${ }^{22}$ J. Cho, Y.-W. Kim, B. Kim, J.-G. Lee, and B. Park, Angew. Chem., Int. Ed. 42, 1618 (2003).

${ }^{23}$ P. Poizot, S. Laruelle, S. Grugeon, L. Dupont, and J.-M. Tarascon, Nature (London) 407, 496 (2000). 